\title{
ECO-FRIENDLY SYNTHESIS, SPECTRAL AND BIO- POTENTIAL INVESTIGATION OF Zn(II) AND Ni(II) COMPLEXES WITH BIO-ACTIVE SCHIFF BASE
}

\author{
C. Veeravel ${ }^{\bowtie}$, K. Rajasekar, S. Balasubramaniyan and R. Selvarani \\ PG \& Research Department of Chemistry, Govt. Arts College, Ariyalur-621713, \\ Tamil Nadu, India (Affiliated to Bharathidasan University) \\ ${ }^{\square}$ Corresponding Author: cveeravel.ml@gmail.com
}

\begin{abstract}
A new bio-active Schiff base was synthesized from cinnamaldehyde and aniline and the $\mathrm{Zn}(\mathrm{II}), \mathrm{Ni}(\mathrm{II})$ metal complexes have been synthesized and structurally characterized by micro-analytical, magnetic property, conductivity, mass spectra, FT-IR, Electronic absorption spectra, ${ }^{1} \mathrm{H}-\mathrm{NMR}$, and ${ }^{13} \mathrm{C}-\mathrm{NMR}$ spectral studies. The Physico-chemical and spectral data show that the complexes have the composition of 1:1 type of metal with a ligand. Its electronic absorption spectra and magnetic study proposed the tetrahedral geometry for $\mathrm{Zn}$ (II) complex and octahedral geometry for $\mathrm{Ni}(\mathrm{II})$ complex. It was further supported by the mass and IR spectra; the biological activities of Schiff base and their metal complexes were carried out by the Agar disc diffusion method. The results confirmed that the metal complexes enhanced the bio-potential activities than the free Schiff base.
\end{abstract}

Keywords: Schiff Base, Zn(II) Complex, Ni(II) Complex, Antibacterial, Antifungal

RASĀYAN J. Chem., Vol. 14, No.4, 2021

\section{INTRODUCTION}

Schiff base essential chelate compounds due to their stability, chelating properties and biological applications. ${ }^{1}$ The nitrogen and oxygen donor atoms present in Schiff base are greater attention. In this area has been focused on the complexes formed by the transition metal ions with Schiff base. So the Schiff is an important ligand in coordination chemistry. ${ }^{2,3}$ The presence of azomethine $(\mathrm{C}=\mathrm{N})$ linkage in Schiff base and its metal(II) complexes show a wide range of biocidal activities such as antibacterial, antifungal, herbicidal, anti-inflammatory, anticancer, antidiabetic and antitumor activities. ${ }^{4-6}$

Zinc has been involved in several biological processes in the form of complexes in human beings, proteins and nucleic acids. Zinc deficiency causes several neurological diseases, which can be identified by uptake, accumulation and trafficking of zinc ion., it is also used to treat diabetes, cancer, antiinflammatory and cardiovascular disease. ${ }^{9-11}$ ' $\mathrm{N}$ ' and ' $\mathrm{O}$ ' donor Chelating ligands show broad biopotential activity due to the binding nature of the complex. ${ }^{12}$

\section{Synthesis of Schiff Base}

\section{EXPERIMENTAL}

A solution of Benzenamine $0.462 \mathrm{~g}(4.9 \mathrm{mmol})$ in $10 \mathrm{ml}$ ethanol, $0.668 \mathrm{~g}(5.0 \mathrm{mmol})$ of (2E)-3-phenyl prop-2-enol in $10 \mathrm{ml}$ Diethyl ether was mixed in a beaker, and add $15 \mathrm{ml}$ distilled water as a catalyst. The whole mixture was stirred for $10 \mathrm{~min}$ at room temperature with constant stirring. The pale-yellow precipitated powder was formed and the reaction mixture was filtered, and washed with distilled water, dried in desiccators at kept in an airtight glass container then has been used in green technic synthesis.

\section{Synthesis of $\mathrm{Zn}(\mathrm{II})$ Complex}

A solution of $1.00 \mathrm{~g}$ (3.3 mmole) of Zinc(II)nitrate hexahydrate in $10 \mathrm{ml}$ methanol, $1.3936 \mathrm{~g}(6.7 \mathrm{mmol})$ (E-N-((E)-3-phenyl allylidene)aniline in $20 \mathrm{ml}$ ethanol and $0.450 \mathrm{~g}(3.3 \mathrm{mmol})$ oxalate in $20 \mathrm{ml}$ distilled water were mixed thoroughly and add $15 \mathrm{ml}$ distilled water as a catalyst with 10 min constant stirring at RT. The colorless precipitate was formed, filtered, washed with distilled water and dried in desiccators and kept in an airtight glass container. The metal complex is soluble in ethanol.

Rasayan J. Chem., 14(4), 2285-2291(2021)

http://doi.org/10.31788/RJC.2021.1446672

This work is licensed under a CC BY 4.0 license. 
RASĀYAN J. Chem.

Vol. 14 | No. 4 |2285-2291| October- December | 2021

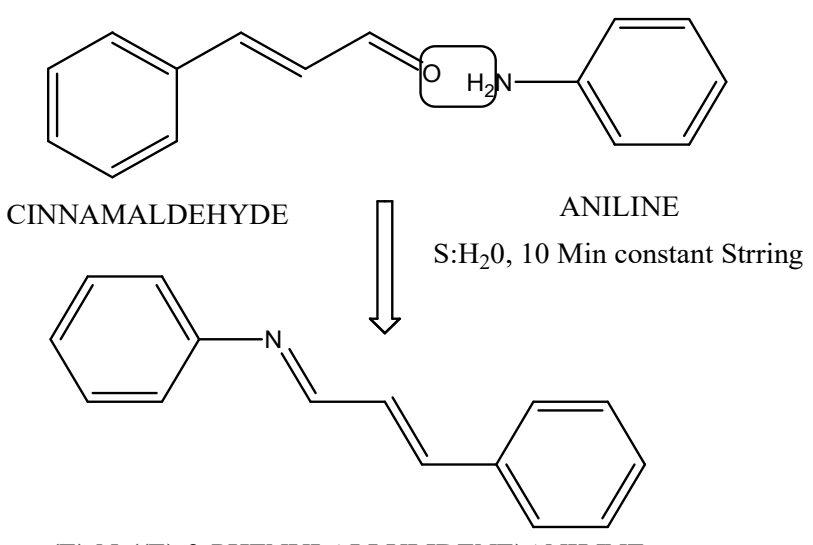

(E)-N-((E)-3-PHENYLALLYLIDENE)ANILINE

Fig.-1: Synthesis of Schiff Base
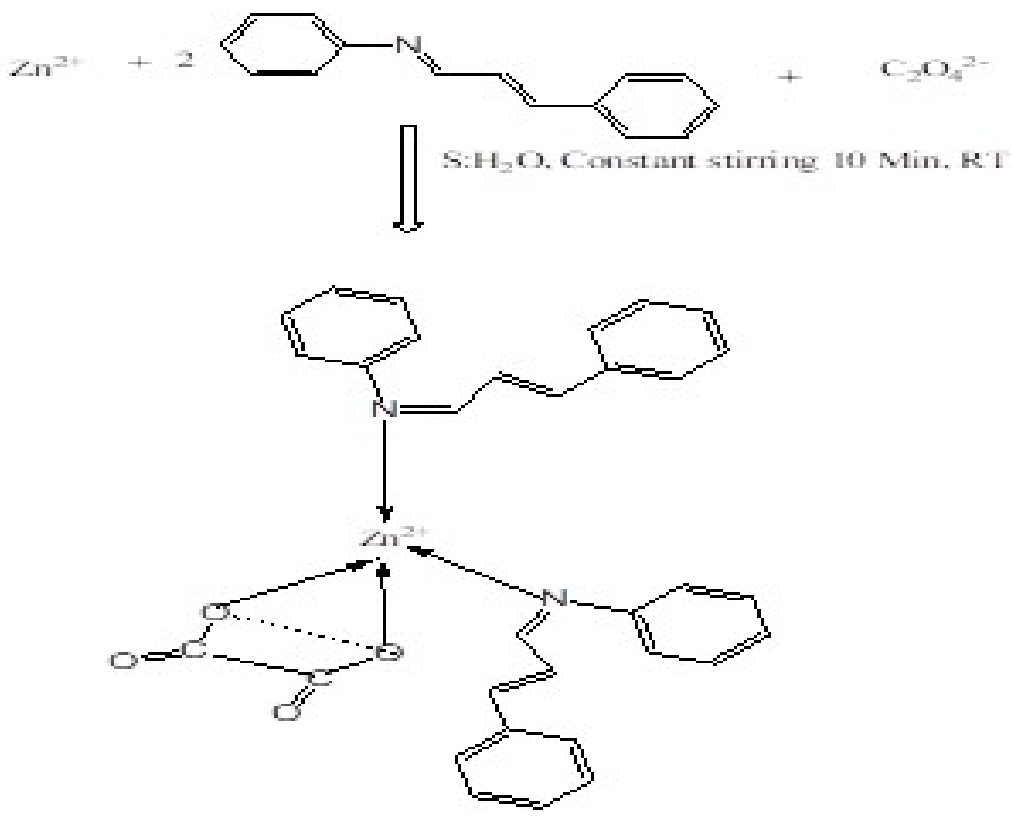

Fig.-2: Synthesis of Zn(II) Complex

\section{Synthesis of Nickel Complex}

$1.00 \mathrm{~g}(3.40 \mathrm{mmol})$ nickel nitrate was dissolved in $10 \mathrm{ml}$ methanol and $2.851 \mathrm{~g}(13.7 \mathrm{mmol})$ of ligand (E$\mathrm{N}-((\mathrm{E})-3$-phenyl allylidene)aniline dissolved in $35 \mathrm{ml}$ ethanol and the anionic ligand of oxalate $0.460 \mathrm{~g}$ ( $3.40 \mathrm{mmole}$ ) dissolved in $25 \mathrm{ml}$ distilled water the whole mixture was stirred for about $10 \mathrm{~min}$ at room temperature with $15 \mathrm{ml}$ distilled water used as a catalyst. The pale green precipitate was formed, filtered, dried in desiccators and kept in an air-tight glass container. The metal complex is soluble in ethanol.

\section{Materials and Method}

These studies used the following reagents, such as AnalaR grade purchased without further purification. Aniline, cinnamaldehyde, sodium oxalate, Zinc nitrate hexahydrate and Nickel nitrate hexahydrate were AnalaR grades. Solvents such as methanol and ethanol were used. The elemental analysis was carried out using Thermo Finnegan make, Flash EA1112 model CHNS(O) analyzer instrument. The molar conductance of $10^{-3} \mathrm{M}$ complexes in acetonitrile was conducted using Systronic Conductivity Bridge at $300^{\circ} \mathrm{C}$. Solid-state spectra of metal chelates (DRS-method) were characterized by using JASCO model No: V-650 make UV-VIS spectrophotometer in the range of 200-800nm. The FT-Infrared spectra of 
Schiff base and the metal chelates were recorded using $\mathrm{KBr}$ pellet technique by Perkin Elmer spectrum, ONE-NO17-1159 Spectrometer in the range of 4000-400 $\mathrm{cm}^{-1}$ and the ${ }^{1} \mathrm{H}$ and ${ }^{13} \mathrm{C}$ NMR spectra of Zn(II) complex was recorded using BRUKER AS-3590-I spectrometer in $\mathrm{d}_{6}$-DMSO and $\mathrm{CDCl}_{3}$. The biological activities of Schiff base and the metal complexes were carried out by Agar disc diffusion method.

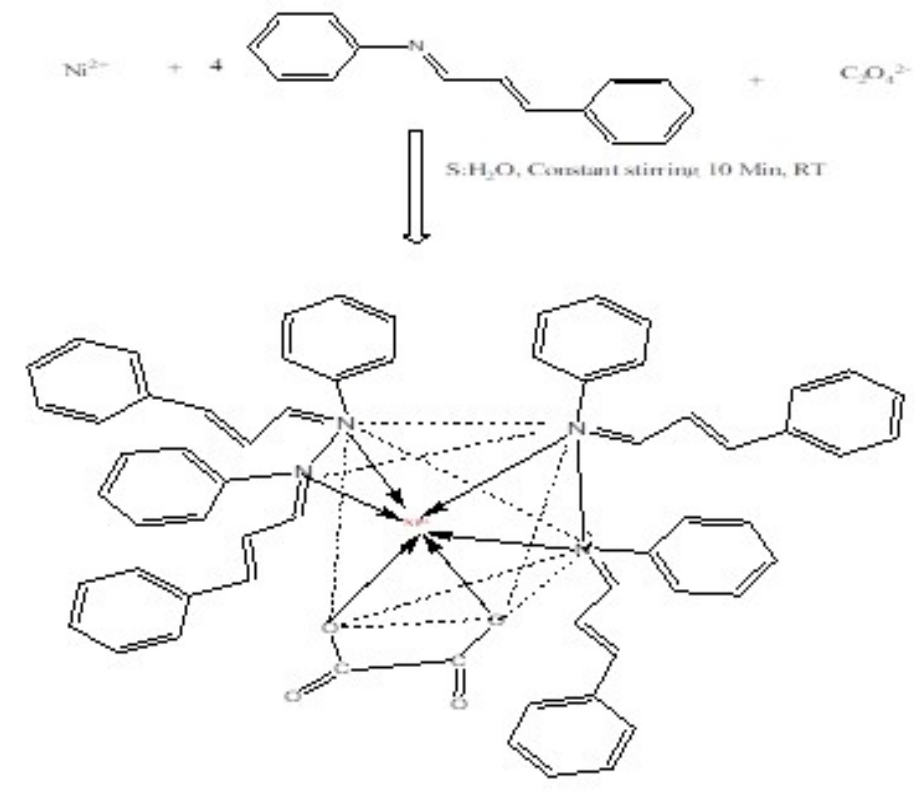

\section{Antimicrobial Assay}

Fig.-3: Synthesis of Ni(II) Complex

The Schiff base and complexes were screened for their biological activity against four bacterial strains, namely Escherichia coli, Staphylococcus aureus, Bacillus subtilis and Pseudomonas aeruginous and two fungal strains viz., Candida Albicans \& A. Niger were obtained from Microbial type culture collection (MTCC) at the Institute of Microbial Technology (IMTECH), Chandigarh, India. The discs measuring 6.0 $\mathrm{mm}$ in diameter were punched from Whatman No.1 filter paper. Petri plates were prepared by pouring 30 $\mathrm{ml}$ of Nutrient agar (NA) medium and Potato dextrose agar (PDA) medium. The plates were incubated at $37{ }^{\circ} \mathrm{C}$ for 24 hours for the bacterial strain and 48 hours for fungal strains and the experiments were done by triplicates for each sample. The discs of each concentration were placed in a nutrient agar medium inoculated with fresh bacterial strains separately. Each disc was added $100 \mu 1$ of test samples, standard drug as Chloramphenicol $(10 \mathrm{mg} / \mathrm{ml}$ distilled water) for bacteria and Fluconazole $(10 \mathrm{mg} / \mathrm{ml}$ distilled) for fungi separately. The antimicrobial potential of test compounds was determined based on the mean diameter of the zone of inhibition around the disc in millimeters. The zones of inhibition of the tested microorganisms by the samples were measured using a millimeter scale.

\section{Micro-analysis}

\section{RESULTS AND DISCUSSION}

The metal complexes are forming in a 1:1 stoichiometric ratio based on the elemental analysis. The ligand and the metal (II) complexes were found in good yield. The distilled water and organic moisture were removed and the ligand is yellow while $\mathrm{Zn}(\mathrm{II})$ complex is colorless, but $\mathrm{Ni}(\mathrm{II})$ is green in color. The decomposition temperature of the Schiff base is about $125^{\circ} \mathrm{C}$. They are very stable solid under ordinary conditions. The complexes are not hygroscopic and insoluble in distilled water and other common organic solvents but soluble in DMF and DMSO. The low molar conductance value of the complexes (measured in $10^{-3} \mathrm{M} \mathrm{CH}_{3} \mathrm{CN}$ ) indicating the non-electrolyte nature of the complex. ${ }^{13}$ The analytical data and molar conductance values are given in the Table-1. 
RASĀYAN J. Chem.

Vol. 14 | No. 4 |2285-2291| October- December | 2021

Table-1: Analytical Data of the Schiff Base and Its Complexes

\begin{tabular}{c|l|c|c|c|c|c}
\hline \multicolumn{7}{c}{ Elemental Analysis (Theoretical Values) } \\
\hline S. No. & Complex/Ligand & $\begin{array}{c}\% \mathrm{C} \\
(\exp )\end{array}$ & $\begin{array}{c}\% \mathrm{H} \\
(\exp )\end{array}$ & $\begin{array}{c}\% \mathrm{~N} \\
(\exp )\end{array}$ & $\begin{array}{c}\% \mathrm{O} \\
(\exp )\end{array}$ & $\begin{array}{c}\text { \%Metal } \\
(\exp )\end{array}$ \\
\hline 1 & $\left(\mathrm{C}_{15} \mathrm{H}_{13} \mathrm{~N}\right)$ & 86.83 & 06.27 & 06.75 & - & - \\
& & $(86.81)$ & $(06.25)$ & $(07.00)$ & & \\
\hline 2 & {$\left[\mathrm{Zn}\left(\mathrm{C}_{15} \mathrm{H}_{13} \mathrm{~N}\right)_{2}\left(\mathrm{C}_{2} \mathrm{O}_{4}\right)\right]$} & 67.60 & 04.57 & 04.92 & 11.26 & 11.51 \\
& & $(67.55)$ & $(04.17)$ & $(05.00)$ & $(11.20)$ & $(11.50)$ \\
\hline 3 & {$\left[\mathrm{Ni}\left(\mathrm{C}_{15} \mathrm{H}_{13} \mathrm{~N}\right)_{4}\left(\mathrm{C}_{2} \mathrm{O}_{4}\right)\right]$} & 78.91 & 05.51 & 05.93 & 06.78 & 06.22 \\
& & $(78.50)$ & $(05.41)$ & $(6.01)$ & $(06.92)$ & $(06.03)$ \\
\hline
\end{tabular}

Table-2: Elemental Analysis

\begin{tabular}{c|c|c|c|c|c|c|c}
\hline $\begin{array}{c}\text { S. } \\
\text { No. }\end{array}$ & Complex/Ligand & Color & $\begin{array}{c}\text { Melting } \\
\text { Point } \\
\left({ }^{\circ} \mathrm{C}\right)\end{array}$ & $\begin{array}{c}\text { Yield } \\
(\%)\end{array}$ & $\begin{array}{c}\text { Molar } \\
\text { Conductance } \\
\text { Ohm- }^{-1} \mathrm{~cm}^{2} \mathrm{~mol}^{-} \\
1\end{array}$ & $\mu_{\text {eff }}[\mathrm{BM}]$ & $\begin{array}{c}\lambda_{\max } \\
\left(\mathrm{cm}^{-1}\right)\end{array}$ \\
\hline 1 & $\left(\mathrm{C}_{15} \mathrm{H}_{13} \mathrm{~N}\right)$ & $\begin{array}{c}\text { Pale } \\
\text { Yellow }\end{array}$ & 125 & 71.42 & 20.00 & - & 38314 \\
\hline 2 & {$\left[\mathrm{Zn}\left(\mathrm{C}_{15} \mathrm{H}_{13} \mathrm{~N}\right)_{2}\left(\mathrm{C}_{2} \mathrm{O}_{4}\right)\right]$} & Colourless & 180 & 72.72 & 25.00 & Diamagnetic & 15360 \\
\hline 3 & & Pale Green & 185 & 73.52 & 20.00 & 3.7 & 35971 \\
& {$\left[\mathrm{Ni}(\mathrm{SB})_{4}\left(\mathrm{C}_{2} \mathrm{O}_{4}\right)\right]$} & & & & & & 27100 \\
& & & & & & 17094 \\
\hline
\end{tabular}

\section{Mass Spectrum of Schiff Base}

The ESI mass spectral fragmentation of Schiff base showed the $\mathrm{m} / \mathrm{z}$ value at 207 determinations through the formula and molecular weight, the other two $\mathrm{m} / \mathrm{z}$ values of 115 and 89 representing the fragment of $\mathrm{C}_{9} \mathrm{H}_{8}{ }^{+}$and $\mathrm{C}_{6} \mathrm{H}_{7} \mathrm{~N}^{-}$.

\section{IR Spectra}

IR spectra of the metal chelates indicated the bonding nature of the Schiff base with the metal ion. The FT-IR spectrum of Schiff base shows the stretching frequency at $1621 \mathrm{~cm}^{-1}$ corresponding to $\mathrm{v}(\mathrm{C}=\mathrm{N})$ azomethine stretching mode indicating the formation of the Schiff base from cinnamaldehyde and aniline. This band was shifted to higher frequencies in the metal complexes at $1624 \& 1621 \mathrm{~cm}^{-1}$, indicating the involvement of the azomethine nitrogen in coordination with the metal ion. ${ }^{14}$ To reduce the electron density of the azomethine link, the coordination of nitrogen to the metal ion could be expected and thus which was caused by a shift in the $\mathrm{v}(\mathrm{C}=\mathrm{N})$ group. The intense band at $3053 \mathrm{~cm}^{-1}$ present in the IR spectrum of the free ligand should be assigned to the complexes at $3351 \& 3350 \mathrm{~cm}^{-1}$ for the stretching frequency of $\mathrm{v}(\mathrm{C}-\mathrm{CH})$. The IR spectra of the mononuclear metal (II) complex also showed broadband in the $\mathrm{r}(\mathrm{C}=\mathrm{C})$ at $1920 \& 1980 \mathrm{~cm}^{-1}$ region, in line with the presence of free ligand that shows $1953 \mathrm{~cm}^{-1}$. The coordination of the metal ion of Schiff base have conclusive evidence of the bonding and shown new bands in the spectra of all metal complexes that appearing in the low-frequency regions at $374-343 \mathrm{~cm}^{-1}$ and $482 \mathrm{~cm}^{1}$ for $\mathrm{Zn}$ (II) and 342-340 and $486 \mathrm{~cm}^{-1}$ for $\mathrm{Ni}(\mathrm{II})$ characteristic to (M-O) and (M-N) stretching vibrations, respectively, whereas, free ligands not observed in the spectrum. ${ }^{15-16}$

\section{Absorption Spectrum}

$\mathrm{Zn}$ (II) complex did not show d-d transition in the visible region because of filled $3 \mathrm{~d}$ orbitals. $\mathrm{Zn}$ (II) metal complex is diamagnetic with no magnetic moment value indicating the four-coordinated tetrahedral geometry around the $\mathrm{Zn}(\mathrm{II})$ metal ion. ${ }^{17}$ The electronic spectrum of $\mathrm{Ni}(\mathrm{II})$ complex gives the absorption band in the region of $278 \mathrm{~nm}, 369$ and $585 \mathrm{~nm}$ respectively corresponding to the $\pi \rightarrow \pi^{*},{ }^{3} \mathrm{~A}_{2 \mathrm{~g}} \rightarrow{ }^{3} \mathrm{~T}_{\mathrm{gg}}(\mathrm{F})$ : $\mathrm{n} \rightarrow \pi^{*},{ }^{3} \mathrm{~A}_{2 \mathrm{~g}} \rightarrow{ }^{3} \mathrm{~T}_{1 \mathrm{~g}}(\mathrm{P})$ and ${ }^{3} \mathrm{~A}_{2 \mathrm{~g}} \rightarrow{ }^{3} \mathrm{~T}_{2 \mathrm{~g}}$ transitions indicating the octahedral geometry which is further 
RASĀYAN J. Chem.

Vol. 14 | No. 4 |2285-2291| October- December | 2021

confirmed by the magnetic moments ranging from 2.90 to 3.70 B.M. depending on the orbital angular momentum contribution the complex show octahedral geometry. ${ }^{18}$

\section{${ }^{1} \mathrm{H}$ and ${ }^{13} \mathrm{C}-\mathrm{NMR}$ Spectra}

${ }^{1} \mathrm{H}-\mathrm{NMR}$ spectrum of Schiff base shows different proton environmental chemical shift values at H17.135-7.153, H2-7.206-7.209, H3-7.221-7.239, H4-6.586-6.589, H5-6.565-6.567, H6-7.439-7.443, H77.342-7.359, H8-7.370-7.374 and H9-7.382-7.31 respectively which are indicating the formation of Schiff base by deprotonation after condensation of cinnamaldehyde and aniline. In $\mathrm{Zn}$ (II) complex these chemical shift values (Figure-4\&5) are shifted to the down of the up-field region by effective coordination of Schiff base to the metal ion. It has further confirmed by 11 different carbon atoms present in the Schiff base at C1-128.04, C2-128.69, C3-126.50, C4-135.85, C5-144.81, C6-120.31, C7-162.51, C8-151.71, C9-121.63, C10-130.11 and C11-127.69 chemical shift values respectively shifted to down or upfield region. ${ }^{19-20}$
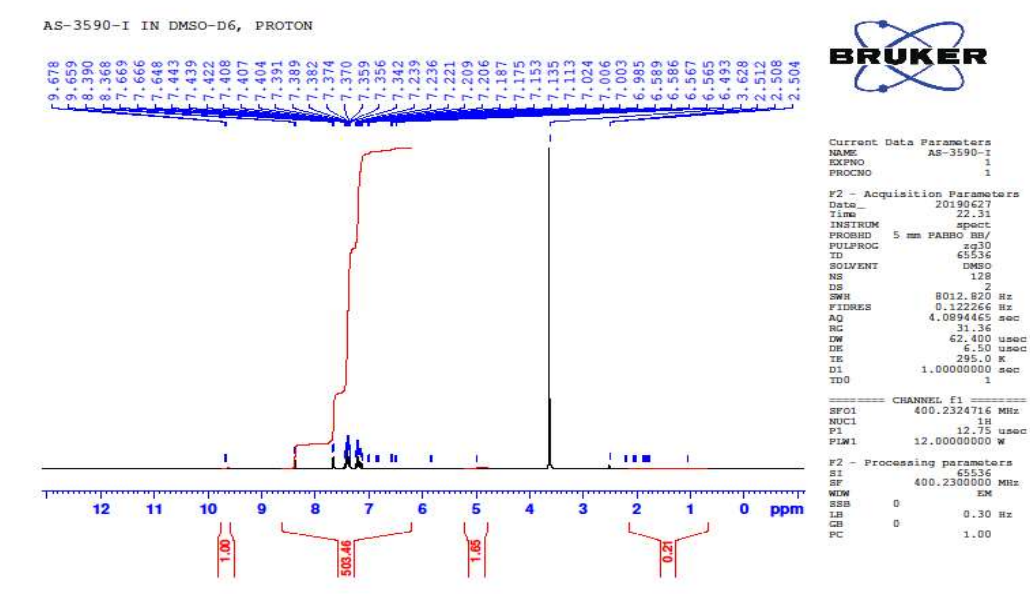

Fig.-4: ${ }^{1} \mathrm{H}-\mathrm{NMR}$ Spectrum of Zn(II) Complex
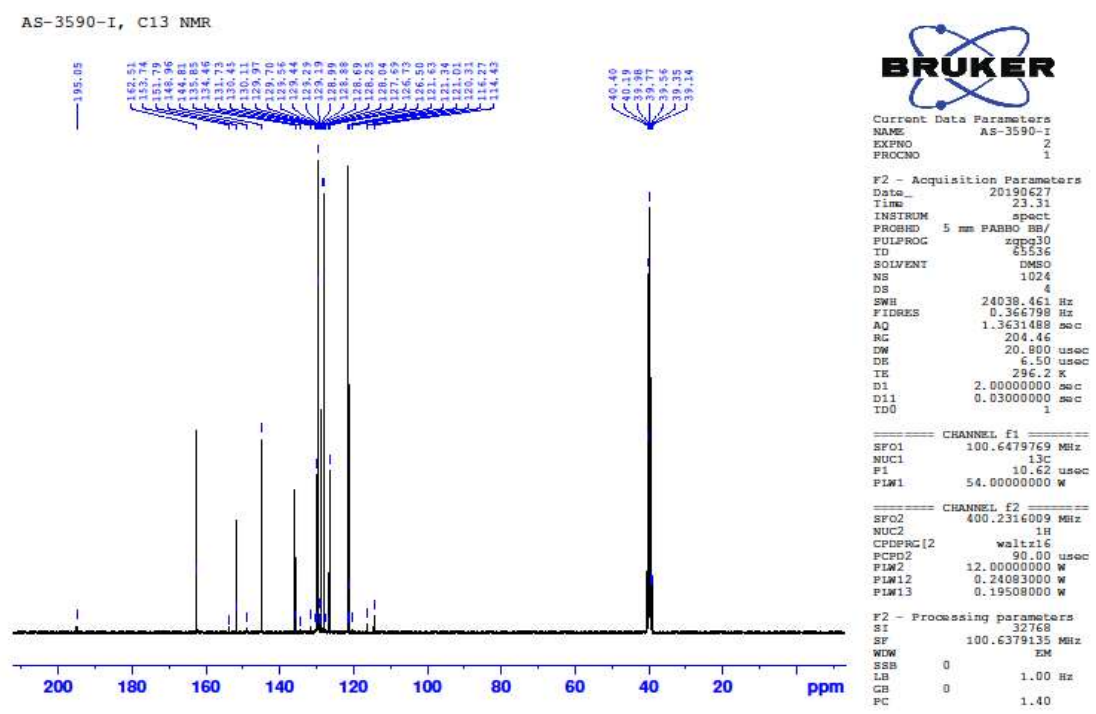

Fig.-5: ${ }^{13} \mathrm{C}-\mathrm{NMR}$ Spectrum of $\mathrm{Zn}(\mathrm{II})$ Complex 
RASĀYAN J. Chem.

Vol. 14 | No. 4 |2285-2291| October- December | 2021

\section{Antimicrobial Activities}

The ligand and metal complex have been screened for antibacterial and antifungal activities shown in (Fig.-6). The antibacterial activity of the Schiff base and its complex against four strains of bacteria, Escherichia coli, Staphylococcus aureus, Bacillus subtilis \& Pseudomonas aeruginous and active again the fungal species of $A$. niger and $C$. albicans. The effectiveness of the complex of Schiff base is classified into three categories, highly active, moderate, and Resistant. If a compound is highly active to bacteria, then it can be applied to cure the disease caused by the bacteria, while it has failed in the resistant bacteria. Accordingly, the effectiveness was determined in the predicted compound through the zone of inhibition $(\mathrm{mm})$. The results showed that they represent ligand was found to possess more antibacterial and fungal activity than the complex against different bacteria. Due to the presence of chelates ring possess $\pi$ electron delocalization, which enhances biological activities. ${ }^{21-22}$

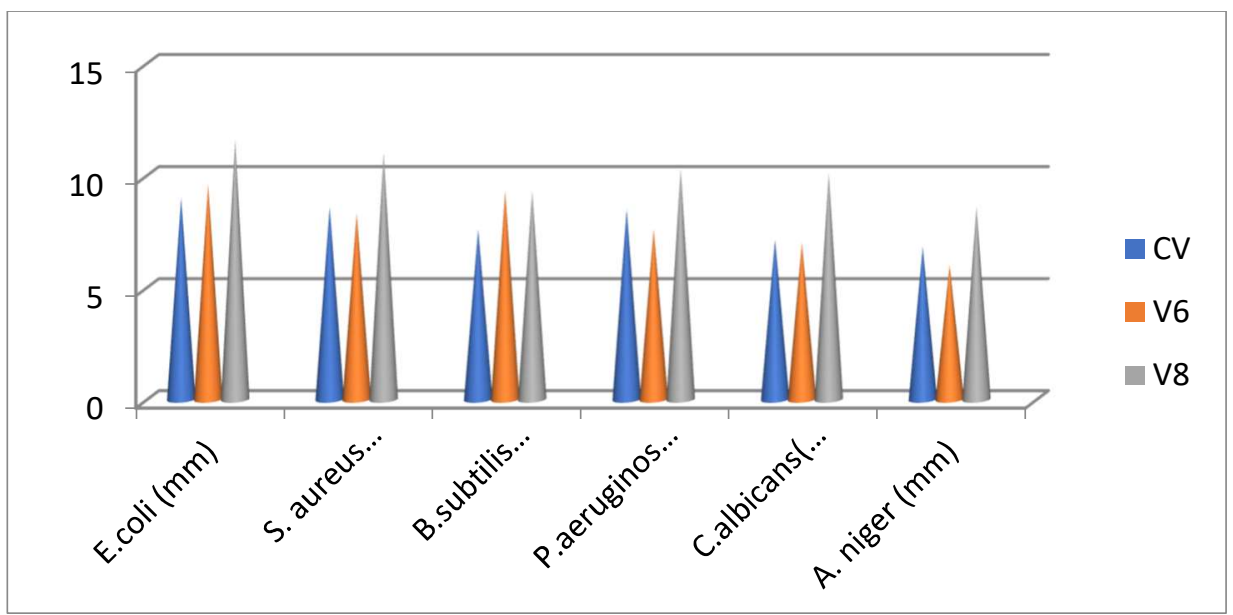

Fig.-6: Antimicrobial Activities

Cv- Schiff Base, V6- Ni(II) Complex, V8- Zn(II) Complex

\section{CONCLUSION}

The present studies concluded that the synthesis of Schiff base from amine and aldehyde such as aniline and cinnamaldehyde by green route method and the metal complexes also synthesized by the same method. The octahedral mononuclear nature of Ni(II) complex and mononuclear tetrahedral geometry of $\mathrm{Zn}$ (II) complex was confirmed based on the data of UV, IR, NMR and magnetic property. All the complexes are non-electrolytes, neutral in nature and the formulae of the complexes are also confirmed by elemental analysis and conductivity. They have shown enhanced bio-potential activities against tested microorganisms.

\section{ACKNOWLEDGEMENT}

The authors are thankful to the Principal, Head Department of Chemistry, Govt. Arts College, Ariyalur for providing facilities available at the Department. The Authors are very much grate full to the Head and Staff Members of SAIF, Mumbai, Chennai, Cochin and Harman Research Lab for providing spectral and biological activities.

\section{REFERENCES}

1. Subhankar Kundu, Ajoy Kumar, Apurba sau mondal, Pramanik, Tapan Kumar Mondal, Molecular Structure, 111, 1(2016), https://doi.10.1016/j.molstruc.2016.03.013

2. A.A. Abdel Aziz, A.N.M. Salem, M.A. Sayed, M.M. Aboaly, Journal Of Molecular Structure, 1010, 130(2012), https://doi.org/10.1016/j.molstruc.2011.11.043

3. A. Go lcu, M. Tumer, H. Demirelli, R.A. Wheatley, Inorganic Chimica Acta, 358(6), 1785(2005), https://doi.org/10.1016/j.ica.2004.11.026

4. N. Raman, S. Sobha, A. Thamaraichelvan, Spectrochim Acta Part A, 78, 888(2011), https://doi.org/10.1016/j.saa.2010.12.056 
RASĀYAN J. Chem.

Vol. 14 | No. 4 |2285-2291| October- December | 2021

5. Yong Li, Zheng YinYang, Jin CaiWu, Europian Journal of Medicinal Chemistry, 45(12), 5692(2010), https://doi.org/10.1016/j.ejmech.2010.09.025

6. K. C. Gupta and A. K. Sutar, Coordination Chemistry Reviews, 252(12-14),1420(2008), https://dx.doi.org/10.1016/j.ccr.2007.09.005

7. Mohammad Azam, Saud. I. Al-Resayes, Raghavaiah Pallepogu, Farha Firdaus, Mohammad Shakir, Journal of Saudi Chemical Society, 20, 120(2016), https://doi.org/10.1016/j.jscs.2015.11.005

8. Ghana Raymoni, Hijazi Abu Ali, Applied Organometalic Chemistry, 33 e4680(2019), https://doi.org/10.1002/aoc.4680

9. S.P. Fricker, Dalton Transactions, 43, 4903(2007), https://doi.org/10.1039/B705551J

10. R.R. Crichton, D.T. Dexter, R.J. Ward, Coordination Chemistry Reviews, 252, 1189(2008)

11. R. Cini, G. Tamasi, S. Defazio, M.B. Hursthouse, Journal of Inorganic Biochemistry, 101, 1140(2007), https://doiI:10.1016/j.jinorgbio.2007.04.015

12. Nayaz Ahmed, Mohd Riaz, Altaf Ahmed, and Madhulika Bhagat, International Journal of Inorganic Chemistry, Article ID 607178 (2015), https://doi.org/10.1155/2015/607178

13. C. Karakayaa, B. Dedeb and E. Cicek, Acta Physica Polonica A, 129 (2016)

14. N. Raman, S. Sobha, L. Mitu, Journal of Saudhi Chemical Society,17,151(2013), https://doi.org/10.1016/j.jscs.2011.03.003

15. Gajendra Kumar, Dharmendra Kumar, Shoma Devi, Rajeev Johari, C.P. Singh, European Journal of Medicinal Chemistry,45, 3056(2010), https://doi.org/10.1021/ic0605064

16. Mohammad Habibi , S. Ali Beyramabadi a, SadeghAllameh, Maryam Khashi, Ali Morsali, Mehdi Pordel, Mahdi Khorsandi-Chenarboo, Journal of Molecular Structure, 1143, 424(2017), https://doi.org/10.1016/j.molstruc.2017.04.114

17. Anthony C. Ekennia, Damian C. Onwudiwe, Lukman O. Olasunkanmi, Aderoju A. Osowole, and Eno E. Ebenso, Bioinorganic Chemistry and Applications, 789063, (2015), https://doi.org/10.1155/2015/789063

18. Arghya Basu, Durairaj Thiyagarajan, Chirantan Kar, Aiyagari Ramesh and Gopal Das, RSC Advances, 3, 14088(2013), https://doi.org/10.1039/C3RA40904J

19. Saadallah Ramadan, Trevor W. Hambley, Brendan J. Kennedy, and Peter A. Lay, Inorganic Chemistry, 43(9), 2943(2004), https://doi.org/10.1021/ic0352811

20. De Gruyter, Open Chemistry, 17(1), 936(2019), https://doi.org/10.1515/chem-2019-0108

21. Senthilkumar Balakrishnan, Senbagam Duraisamy, Murugan Kasi, Selvam Kandasamy, Rajesh Sarkar, Anbarasu Kumarasam, Heliyon 5, e01687, (2019), https://doi.org/10.1016/j.heliyon.2019.e01687

[RJC-6672/2021] 